\title{
Customers' behaviour during purchasing vegetarian products in global retail environment
}

\author{
František Milichovský, ${ }^{1, *}$, and Pavel Mráček ${ }^{1}$ \\ ${ }^{1}$ Brno University of Technology, Faculty of Business and Management, Department of management, \\ Kolejní 2906/4, 61200 Brno, Czech Republic
}

\begin{abstract}
Purpose Behaviour in food purchasing is usually associated with personal identity. Vegetarian's apologist has diverse attitude vis-à-vis animals and the environment, which affect global nature in the context of national agriculture production. According to comparison vegans with vegetarians, vegetarians are quite tolerant of other animal products except for meat products. Worldwide, vegans do not accept any animal products of animals. That approach should impact requirements on food offer and perception of potential customers. Methods There were employed questionnaire survey, where there were asked 1389 persons to participate in the primary research. From this amount we receive 395 questionnaires, what mean $28,44 \%$ returned forms. Findings According to respondents' gender, there were participated in 212 women $(53,67 \%$ of all participants) and 183 men (46,33\% of all participants). For evaluation of gained data, there was applied Pearson's chi-square test for independence of variables. The main objective of the paper is to find a connection between suggestions of vegetarianism and gender of target potential customers. From survey authors chose general opinions about vegetarianism, which represents feelings of participants: (1) is vegetarianism healthful; (2) does vegetarianism not include enough nutrients for humans, (3) is vegetarianism danger for child evolution, (4) is a human body adapted to meat consummation, (5) help vegetarians to reach higher age. All of these variables were put into evaluation of dependence with gender by Pearson's chi-square test.
\end{abstract}

\section{Introduction}

Nowadays, there are a lot of people, which awow to be a vegetarian or profess specific alimentary tendency, but they usually meet lack of misunderstanding of wide audience in alternate ways of messing and nutrition approaches. Vegetarianism includes wide potential approaches, which are divided from basic form. In general, these approaches have got bigger interests worldwide and number of people increasing during present time. Therefore, this lifestyle has become more popular, and get better range of services and sortiments.

Vegetarianism includes several kinds of alternative food-manners, which are diffirent from common food-manners. From point of view of nutrition value, some of these alternatives could be considered as good and bad at same time, depending on individual's

*Corresponding author: milichovsky@fbm.vutbr.cz 
needs. Alternative nutrition usually exclude some kinds of foodstuff (typically meat or diary products) or their processing, what is main different from common nutrition approach $[1,2,3]$.

Vegetarianism repreresents framework of nourishment, which exclude meat nad parts of animals, which are gained by killing. Other products of animals are not banned. From point of view of vegetarianism subsystems there could be different approaches in excluding products [4], which could be based on economical reasons [5], nutrition requirements [6], [7] or nutrition knowledge of consumers [8,9].

\subsection{Vegetarianism as lifestyle}

The term vegetarianism represents a specific system of nourishment, which strictly excludes all meat products and animal body parts, reached by killing animals [8]. People profess vegetarianism do not deprecate animal products such as milk, milk products, honey, and others. As a specific kind of vegetarianism could be considered veganism, which eliminates all meals of animals and accepts only plant products [11].

Vegetarianism is rated as behaviour, by which man reject meat in all variations in his meals. Vegetarianism includes specific kinds of vegetarianism, where are defined the specific situation of animal products rejection. All individual kinds of vegetarianism are a long-term approach $[4,12]$. There are many reasons why people accept vegetarianism. At present time, there is main reason healthy lifestyle with the correct regime. A second main reason is kind of ethics standards, consisting abhorrence of non-ethic animal husbandry. Among other reasons, we could add religion, medical or economic [13, 14]:

- healthy reason - according to many studies, vegetarianism is accepted as more natural and more healthy, because it includes a low amount of fat and a lot of vitamins, minerals, and pulps. These positive substances make prevention of heart attack;

- ethic reason - ethic standards and respect for animals should be marked as one of the oldest reason for vegetarianism. Ethic reason does not focus only on killing an animal for the meal, but of course on the specifics of animal husbandry;

- economic reason - the main purpose is lack of finance because vegetarianism is in core much cheaper. It is better to produce plant products for more people instead of animal production;

- religion-ascetic reason - is based on love and respect for animals; the most known religion which leads man to vegetarianism is Buddhism. Other religions consider some animals as sacred (e.g. Hinduism), some religions consider pork as dirty and reject it (e.g. Judaism, Islam);

- ecological reason - Meat production burden with an environment, because fields are used for pasturage instead production of vegetable, fruits, and other plant products. At the same time, there is an influence of fertilizers.

Other specific reasons, why customers have become vegetarians (within other dividing according to consume food) are connected to specific environment such [15]:

(1) identity - individual personal feelings and thinking about himself as drive for selfrespecting;

(2) social experiences - impact of social environment against morale, stereotyping, belief or lifestyle on the way to reconfigure own social networks;

(3) gender - thinking about meat products in different ways in light of healthiness;

(4) culture - norms which prohibit eating food, usually based on traditions and habits.

\subsection{Customers' behaviour according to their reaction on communication tool}

Marketing communication should catch attention of target customer. During paying attention to advertisement there is necessary to make interest of customer about target 
product, service, brand or company as inducement for wish to use that subject followed by purchase action [16]. Hence, there is important to put into communication campaign kind of information, which remit to individual receiver, where he/she can get more details about the subject and in case of need purchase.

Vysekalová and Mikeš [17] define as marketing communication all kinds of communication within target market. They consider as basic communication tools advertising, sales promotion, public relations, direct marketing, sponsoring and other new media, including personal selling and packaging.

Lot of marketing communication tools apply general communication models that are used as communication scenario. The most used model has become AIDA, which is also consider as old one. For that reason, this model was reduced into only three steps, represented by abbreviation $\mathrm{CAB}$. Whole process is made by cognition (awareness and learning about target subject), affect (feeling, interest or desire connected to subject), and behaviour (purchasing or borrowing as action). This model's development marketers get more flexible tool on order of steps, which target customers realise in purchasing process [18]. That means, that in case of various order marketers could reach more effective influence of their campaigns on relationship between customer and product [19]. In case of customers' reaction on marketing communication there is eligible to be suitable within defined objectives.

According to Bearden, Ingram and Laforge [20] marketing communication has to try to influence position and behaviour of message's receivers. As main objectives of marketing communication we can treat notify customer about product, prevail and evoke. By marketing communication is reached creation of relationships between all market subjects such producer, seller or distributor with customer across global international market on the way to strengthen market position, increase products' significance and help customers to orientate oneself in the market and appraise global offer of products, especially in meal market [21].

Traditional objectives in marketing communication are transferable to different fields (also to vegetarianism and veganism). Přikrylová and Jahodová [22] describe traditional marketing communication objective as follow:

- information providing;

- creation and stimulation of demand;

- product differentiation;

- emphasize benefit and product value;

- stabilization of turnover;

- establish and care about brand;

- strengthen corporate image.

\section{Methodology}

Marketing communication utensils tools could strongly influence behaviour of customers in the process of decision making process. Main objective of the paper is to find connection between marketing communication tools and suggestions of vegetarianism. Therefore, there was defined hypothesis, that there exist relationship between vegetarianism knowledge and marketing communication utensil. To confirm this hypothesis there was used questionnaire survey as primary research. Whole survey was focused on the topic of nutrition tendencies in group of young people (age from 15 to 30) according to their gender. There were asked 1597 persons to participate in the primary research. From this amount we receive 351 questionnaires, what mean $21,98 \%$ returned forms. According to respondents' gender, there were participated 189 women $(53,8 \%$ of all participants) and 162 men (46,2\% of all participants). On the defined hypothesis there was applied correlation method, which 
provides potential relationship between individual variables. The data were processed by application of statistical software IBM SPSS Statistics 25.

\section{Results}

Main objective of the paper is to find connection between suggestions of vegetarianism and gender of target potential customers. To find out possible connection between gender and vegetarianism's suggestions there was used correlation analysis. As result of the correlation analysis there is showed correlation matrix (see Table 1), where are shown individual correlation values with adequate significances. It is possible to state, that there are fifteen connections between suggestions as variables. Significance values confirmed the juncture by value under 0,05 what means probability of error in acceptation of alternative premise. According to Pearson's correlation values, there are both positive and negative relationships (from point of view of suggestions' meaning).

Table 1. Correlation matrix for chosen variables.

\begin{tabular}{|c|c|c|c|c|c|c|c|}
\hline & & 1 & 2 & 3 & 4 & 5 & 7 \\
\hline \multirow{2}{*}{$\begin{array}{l}\text { healthfulness of } \\
\text { vegetarianism }\end{array}$} & $\begin{array}{c}\text { Pearson } \\
\text { correlation }\end{array}$ & 1 & & & & & \\
\hline & significance & & & & & & \\
\hline \multirow{2}{*}{$\begin{array}{l}\text { vegetarianism } \\
\text { includes lack of } \\
\text { nutrition }\end{array}$} & $\begin{array}{c}\text { Pearson } \\
\text { correlation }\end{array}$ & $-0,587^{* *}$ & 1 & & & & \\
\hline & significance & 0,000 & & & & & \\
\hline \multirow{2}{*}{$\begin{array}{l}\text { vegetarianism is } \\
\text { danger for child } \\
\text { evolution }\end{array}$} & $\begin{array}{c}\text { Pearson } \\
\text { correlation }\end{array}$ & $-0,424^{* *}$ & $0,496^{* *}$ & 1 & & & \\
\hline & significance & 0,000 & 0,000 & & & & \\
\hline \multirow{2}{*}{$\begin{array}{c}\text { human body is } \\
\text { customised for } \\
\text { meat } \\
\text { consummation }\end{array}$} & $\begin{array}{c}\text { Pearson } \\
\text { correlation } \\
\end{array}$ & $-0,360^{* *}$ & $0,401^{* *}$ & $0,401^{* *}$ & 1 & & \\
\hline & significance & 0,000 & 0,000 & 0,000 & & & \\
\hline \multirow{2}{*}{$\begin{array}{c}\text { vegetarians reach } \\
\text { higher age }\end{array}$} & $\begin{array}{c}\text { Pearson } \\
\text { correlation }\end{array}$ & $0,402^{* *}$ & $-0,321^{* *}$ & $-0,227^{* *}$ & $-0,326^{* *}$ & 1 & \\
\hline & significance & 0,000 & 0,000 & 0,000 & 0,000 & & \\
\hline \multirow{2}{*}{ gender } & $\begin{array}{c}\text { Pearson } \\
\text { correlation }\end{array}$ & $0,109^{*}$ & $-0,174^{* *}$ & $-0,122^{*}$ & $-0,226^{* *}$ & $0,123^{*}$ & 1 \\
\hline & significance & 0,024 & 0,000 & 0,012 & 0,000 & 0,011 & \\
\hline
\end{tabular}

${ }^{* *}$ Correlation is significant at the 0.01 level.

${ }^{*}$ Correlation is significant at the 0.05 level.

Correlation matrix shows individual connections between variables. There are also negative values, because there are some suggestions opposite to others. It is obvious, that relationship of suggestion healthfulness of vegetarianism has negative vegetarianism includes lack of nutrition $(-0,587)$, which is divided from their meaning. All values support possibility to application of Pearson chi-square test for independence of variables because of the reached significances of the correlations (see Table 1).

Maintaining the $\%$ reliability of the test, the values for connection between individual factors and company size have been determined within 0.05 , which represents $5 \%$ reliability level. Established values of Pearson's test for the variables are showed in Table 2 (i.e., less than 0.05). Therefore, that bring us to the conclusion that an alternative hypothesis 
is applied - there are dependencies between two linkages of total ten. Subsequently, degree of such dependence has been examined. To that end, the intensity of dependence determined by means of contingency coefficient. The intensity of dependence ranges between $\langle 0 ; 1\rangle$. That means that the higher the absolute value, the greater the intensity of dependence. Table 2 shows that there are two suggestions connected to gender significance values are in 5\% of limit of error. Intensity of the dependence is given by Contingency coefficient, which provides view in this connection. Values for observed relationships reach relevant values (healthfulness of vegetarianism has intensity 0,392; vegetarianism is danger for child evolution reaches 0,411 ), which could be consider as rather average.

Table 2. Observed relationships between chosen variables.

\begin{tabular}{|c|c|c|c|c|}
\hline & & Pearson & Significance & $\begin{array}{c}\text { Contingency } \\
\text { coef. }\end{array}$ \\
\hline \multirow{5}{*}{ 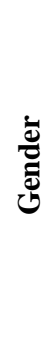 } & healthfulness of vegetarianism & 8,030 & 0,045 & 0,392 \\
\hline & $\begin{array}{c}\text { vegetarianism is danger for child } \\
\text { evolution }\end{array}$ & 2,762 & 0,043 & 0,411 \\
\hline & $\begin{array}{c}\text { vegetarianism includes lack of } \\
\text { nutrition }\end{array}$ & 2,120 & 0,548 & 0,100 \\
\hline & $\begin{array}{c}\text { human body is customised for } \\
\text { meat consummation }\end{array}$ & 5,365 & 0,147 & 0,158 \\
\hline & vegetarians reach higher age & 3,367 & 0,338 & 0,126 \\
\hline \multirow{5}{*}{ : } & healthfulness of vegetarianism & 12,543 & 0,403 & 0,238 \\
\hline & $\begin{array}{c}\text { vegetarianism is danger for child } \\
\text { evolution }\end{array}$ & 6,687 & 0,878 & 0,176 \\
\hline & $\begin{array}{c}\text { vegetarianism includes lack of } \\
\text { nutrition }\end{array}$ & 12,414 & 0,413 & 0,237 \\
\hline & $\begin{array}{c}\text { human body is customised for } \\
\text { meat consummation }\end{array}$ & 12,701 & 0,391 & 0,239 \\
\hline & vegetarians reach higher age & 12,986 & 0,370 & 0,242 \\
\hline
\end{tabular}

\section{Conclusions}

Alternative nutrition way requires knowledge of consumed meal sources, which could be used for evaluation of suitability of specific alternatives. Consumed meal sources reflect rate of main sustenance as proteins, fat and carbohydrates. If chosen messing way consists less admissible nourishment, it could be to consider this way as less suitable for complex meal plan. Vice versa, if spectrum of consumed sources is large, there is build nutrients balance with low probability both of lack and surplus of any individual element. Therefore, if alternative nutrition way allows adequate large spectrum of various meals, it could be consider as relevant food life-style with possibility of other insufficiency [23].

Wide audience usually presents opinions about vegetarianism, which could be consider as kind of myths. Therefore, there were applied statistical verification on the suggestions in connection to gender of final consumers and their education level. According to defined hypothesis relevant data from the survey were processed and Pearson's chi-square test was employed. The gained results of the test confirm two relationships between gender and (1) healthfulness of vegetarianism (significance is 0,045 , intensity of dependence is 0,392 ), and (2) vegetarianism is danger for child evolution (significance is $0,0,43$, intensity of 
dependence is 0,411$)$. Other potential relationships did not reach confirmation of statistical significant dependences (see Table 2).

The results of the survey is supported by mentions of researchers (such [24, 13, 14, 4, $12,25]$ ) who consider vegetarianism as personal decision in connection to the consumer behaviour and lifestyle in global worldwide context.

\section{References}

1. J. Pánek. Základy výživy. Praha: Svoboda Servis (2002)

2. D. Cardenas, Ch. Bermundez, S. Echeverri. Is nutritional care a human right? Clin. Nutr. Exp. 26, 1-7 (2019)

3. C. A. Forestell, J. B. Nezlek. Vegetarianism, depression, and the five factor model of personality. Ecol. Food Nutr. 57(3), 246-259 (2018)

4. M. Stránský, L. Ryšavá. Fyziologie a patofyziologie výživy. 2. dopl. vyd. České Budějovice: Jihočeská univerzita v Českých Budějovicích, Zdravotně sociální fakulta (2014)

5. G. Meunier. Economic assessment of nutritional recommendations: A comment. J. of Health Eco 65, 43-47 (2019)

6. M. Michel, A. Burbidge. Nutrition in the digital age - How digital tools can help to solve the personalized nutrition conundrum. Trends in food Sci \& Tech 90, 194-200 (2019)

7. G. C. Nobre, N. C. Valentini, F. S. Sales Nobre. Fundamental motor skills, nutritional status, perceived competence, and school performance of Brazilian children in social vulnerability: Gender comparison. Child Abuse \& Neglect 80, 335-345 (2018)

8. M. Rivera, A. Shani. Attitudes and orientation toward vegetarian food in the restaurant industry: An operator's perspective. Int. J. Contemp. Hosp. Man. 25(7), 1049-1065 (2013)

9. K. G. Pillai, Y.-S. Liang, D. Thwaites, P. Sharma, R. Goldsmith. Regulatory focus, nutrition involvement, and nutrition knowledge. Appetite 137, 267-273 (2019)

10. G. F. Lieberman. 3,500 Good Quotes for Speakers. Broadway Books, New York (1983)

11. D. L. Rosenfeld, A. L. Burrow. Vegetarian on purpose: Understanding the motivations of plant-based dieters. Appetite 116, 456-463 (2017)

12. T. H. Al-Gahaifi, J. Světlík. Factors influencing consumer behaviour in market vegetables in Yemen. Acta Univ. Agric. Silvic. Mendelianae Brun. 59(7), 17-28 (2011)

13. C. Radnitz, B. Beezhold, J. DiMatteo. Investigation of lifestyle choices of individuals following a vegan diet for health and ethical reasons. Appetite, 90, 31-36 (2015)

14. A. Risi, R. Zürrer. Vegetariánský život: Přednosti bezmassé výživy. Praha: Earth Save (2007)

15. D. L. Rosenfeld. The psychology of vegetarianism: Recent advances and future directions. Appetite 131, 125-138 (2018) Doi 10.1016/j.appet.2018.09.011

16. P. Koudelková. Marketing communication of SMEs acting in creative tourism. In $A$. Királová (Ed.) Driving tourism through creative destinations and activities. Hershey: IGI Global, 375 (2017)

17. J. Vysekalová, J. Mikeš. Reklama : Jak udělat reklamu. 2. akt. a roz. vyd. Praha: Grada Publishing (2007) 
18. D. Kollárová. Podpora predaja pri komunikácií s vybranými cielovými skupinami. Trnava: Fakulta Masmediálnej Komunikácie, Universita Sv. Cyrila a Metoda v Trnave (2014)

19. P. E. Earl, S. Kemp. The Elgar companion to consumer research and economic psychology. Camberley: Edward Elgar Publishing (1999)

20. W. O. Bearden, T. N. Ingram, R. W. Laforge. Marketing, Principles and perspectives. 3rd ed. Boston: McGraw-Hill (2001)

21. N. Kumar, S. Kapoor. Does the consumers' buying behavior differ for vegetarian and non-vegetarian food products? Evidences from an emerging market. Brit. Food J. 117(8), 1998-2016 (2015)

22. J. Přikrylová, H. Jahodová. Moderni marketingová komunikace. Praha: Grada Publishing (2010)

23. J. Fiestas-Flores, A. Pyhälä. Dietary motivations and challenges among animal rights advocates in Spain. Soc. \& Anim. 4(4), 402-425 (2018)

24. E. Leahy, S. Lyons, Tol. An estimate of the number of vegetarians in the world. Working Paper No. 340. Economic and Social Research Institute, Dublin, IR (2010)

25. D. L. Rosenfeld. A comparison of dietarian identity profiles between vegetarians and vegans. Food Qual. Pref. 72, 40-44 (2019) 